ス電極を装置しておかねばならない。われわれは，実 験動物ならびに臨床例において，胃粘膜の $\mathrm{PH}$ を測定 することが出来た：しかし装置を理想的なものにする ためには，電極，リード，および内視鏡をさらに改良 したいと考えているが，将来臨床上大いに役に払つも のと確信している.

\section{8. 食道・胃擦過細胞診用器具の改良}

順天堂大 内科 (消化器科)
白 壁 彦 夫
一代田病院 消化器科

順天堂大 外科

信田重孝沢田好明

食道・胃の微細病変の診断が, 今日診断の焦点とな っている．細胞診は，レ線検查・内視鏡検查・生検組 織診と同様，その重要なきめ手の一つになっている。

現在, 食道や胃の細胞診には，食道・胃ファイバース コーブが用いられ，直視下でおこなわれている．細胞 診にも, 洗滌塗沫法・吸引細胞診·生検塗沫細胞診·擦 過細胞診がある.なかでも，值視下擦過細胞診は，病 変に対する侵襲が少なく，出血をみることも少ない， 採取された細胞は純粋にとり出される，従来の直視下 擦過細胞診用ブラシュは, 食道・胃ファイバースコー プ鉗子孔への細胞のとりこぼしがあり，感染の問題も あった.この久点を補らために，われわれは，オリン パス工業 KKの協力をえて，新しい直視下擦過細胞診 用ブラシュを考案した．従来の直視下擦過細胞診用ブ ラシュにカバーをつけた，手元の操作で，先端内臟の ブラシュが出入りして病変を擦過でさ, 擦過後カバー 内に执めて, 食道・胃ファイバースコープをぬくこ となく，直視下擦過細胞診用ブラシュのみを抜去す る. スライドグラスに塗沫, 組織学的検索に供する. 従一て 1 病変で数力所から，頻回に擦過できる.また 同症例の数病変からも, 病変ご上に細胞をとりこぼし たり，感染することなく，別々に擦過することができ る.なお，町田製作所製のブラシュも小ビニール管を 上おして，食道・胃ファイバースコーブ鉜子孔より挿 入できるようになっている.

われわれは，昭和 45 年 9 月から，このカバ一つきの 擦過細胞診用ブラシュと, 従来の擦過細胞診用ブラシ 二を併用して，食道・胃の細胞診を行なってきてい る. 今问は器具の概要上臨床戊績の検討を報告する.

\section{9. 食道ファイバースコープの改良（特に EF type B, EF pA における臨床応 用面）}

東京女子医大 消化器病センター 遠藤光夫鈴木茂 中村光司山田和毅 牧満竹本忠良 中山恒明

食道ファイバースコープの普及で食道鏡検査は一般 に広くおこなわれよるうになってきた. 種々の改良で 最近の国産品は米国製のものを凌駕するようになっ ている. 今回は食道ファイバースコープのうち，EF type B と EF pa につき, 臨床面を中心にのべてみた いと思う。

EF type B は従来の EF の先端部を 4 方向アングル

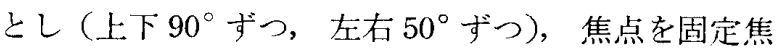
点の他に近位のみ部分的焦点調節式にしたものであ る. 左右アングルの追加で直視下生検時, 鉗子の横方 向への微調整が容易になり小病変の狙撃能が向上し, また食道入口部から上部食道, 下部食道の観察も容易 になった。近位部分的焦点調節で，微細病変の近接扡 大観察, 入口部附近, 食道胃接合部附近の精查に有利 な点を感じている.

EF pa は先端部の径 $7.2 \mathrm{~mm}$, 本体は $6.8 \mathrm{~mm}$ と $\mathrm{EF}$ に比べ細くなり，操作も容易で，患者への苦痛もずっ と少くなった。他の機能面は EF と同じで，観察時は 上もかく, 等真が劣る点を除けば日常の臨床に同じよ うに応用しうると思う.レンズ面 $7 \mathrm{~mm}$ から $45 \mathrm{~mm}$ の明視距離をもち, 視野角は $60^{\circ}$, 先端部は上下に $90^{\circ}$ ずつ屈曲, 操作部の吸引・送気・送水の自動化もみら れる、集検用に，小児の食道鏡検查に，挾窄部の通過 にと応用範用沬広く，臨床例を中心にのべてみるつも りである。

\section{0. 小児の胃内視鏡の開発とその臨床経験}

\author{
東京医大 外科 \\ ○熊沢博久 牧野惟義 \\ 木村幸三郎 小柳 泰久
}

小児の胃十二指腸疾患の診断, 治療効果の判定並び に病態の究明のための小览胃内視鏡検查の意義は大き く，その臨床成果の期待が広く望まれている.

われわれは昭和 45 年 8 月, 教室独自の立場から才リ ンパス光学の協力に上り小巟用胃ファイバースコーブ 